\title{
Educational Policy Development in China in the 21st Century: A Multi-Flows Approach
}

\author{
Jun Li \\ Professor, Faculty of Education, Western University, Canada - Correspond- \\ ing author \\ jun.li@uwo.ca
}

\begin{abstract}
Jian Li
Assistant Professor, China Institute of Education and Social Development, Faculty of Education, Beijing Normal University, Beijing, China jianli2og@bnu.edu.cn
\end{abstract}

\begin{abstract}
Recently China has miraculously transformed itself from a learner in the 2oth century to a re-rising leader of educational excellence. The enduring policy endeavors over the past few decades have largely enabled China as the largest educational system in the world move to a recently emerging status as a global leader of educational improvement, recognized and appreciated with admiration by many traditionally advanced countries. The two authors intend to offer a snapshot of the China miracle of educational development in terms of public policies since the turn of the 21st century. With a Multi-Flows Approach constructed from Csikszentmihalyi's idea of "flow", this paper investigates the complexity and dynamism of three policy streams, i.e., basic education, teacher education and higher education. It is concluded from the literature review that central to China's key policy actions in recent decades are four core themes, i.e., equality in terms of a democratic mission of education for every citizen, quality in terms of individual and social productivity, efficiency as a national priority based on practicality, and rejuvenation of the state for nation-building and global status. Educational policy development in China since the new century is thus examined with economic, political, cultural and international flows, each presenting a colorful jigsaw puzzle that is not easily tessellated by other flows. The authors argue that the different focus of flows and beyond can benefit policy communities in the world with varied directions for educational change resulting in significant improvement while none of them should be seen as a single force in solely shaping educational policy
\end{abstract}


development without the convergence of other forces. This implies that for any public policy in education policymakers, implementers and other stakeholders must ensure a comprehensive consideration of the interdependent, converging effects of these forces to prioritize and maximize their outcomes, which may be easily missed by any single force of them. The implications from this paper sheds new light on policy studies in education in China and globally, and the learner-provider dynamism of educational development in a post-colonial context.

\section{Keywords}

educational policy - China - Multi-Flows - basic education - teacher education higher education - educational improvement - post-colonial context

\section{Introduction 1}

Since the 21st century, education policies in China have aggressively embraced various ideological ideas with regard to localization, globalization, diversification, digitalization, decentralization and marketization, all contributing to the tremendous improvement in the largest system of education in the world. Along with those discourses, numerous educational policies have been initiated and implemented by governmental agencies and educational institutions at various levels, such as The Rejuvenation Action Plan for Education 2003-2007 (2004), The Guidelines of the Mid-and Long-Term Plan for Educational Reform and Development 2010-2020 (2010), The Decision on Speeding up Minorities Education (2015), The Implementation Guidelines for the Comprehensive Promotion for World-class Universities and World-class Disciplines (2017), The Opinions on Enhancing the All-round Capability of Talent Cultivation by Accelerating the Construction of High Quality Undergraduate Education (2018), and The Ten Guidelines of Professional Conduct of Faculty in the New Era (2018). With the mainstream ideologies of educational development, policymakers and practitioners in China have implemented a wide range of policies to respond to varied demands from the political economy of education. The enduring policy endeavors within the past few decades have in part enabled China as the largest educational system in the world move to a recently emerging status as a

1 This paper is unfolded from "Educational policy development in China for the 21st century: Rationality and challenges in a globalizing age" by Jun $\mathrm{Li}$ (2017a) in Chinese Education \& Society, 5o(3), 133-141. 
global leader of educational improvement, given the fact that its achievement is widely recognized and appreciated with admiration by many developed countries. Since the 2010 in a post-colonial context, China has miraculously transformed itself from a learner in the 2oth century to a re-rising leader of international experience of educational excellence.

This paper intends to offer a snapshot of the China miracle of educational development in terms of public policies since the turn of the 21st century. It first reviews the latest studies on education policies in China, with a conclusion of four core themes, i.e., equality in terms of a democratic mission of education for every citizen, quality in terms of individual and social productivity, efficiency as a national priority based on practicality, and rejuvenation of the state for nation-building and global status ( $\mathrm{Li}, 2017 \mathrm{a})$. The two authors then construct a conceptual framework for the analysis of Chinese education policy development based on the emerging idea of Multi-Flows (Csikszentmihalyi, 1975; 2014). With this conceptual framework for analysis, the paper moves to the analysis of three key areas of educational improvement: basic education, teacher education and higher education, followed by the applications of economic flows, political flows, cultural flows and international flows in the examination of educational policy development in China at different levels and times. Last, the paper offers policy implications by reflecting on the MultiFlows Approach and highlighting its applications for the analysis of educational policy development in China since the 2000 .

\section{Latest Studies on Educational Policies in China}

The development of educational policies in China has drawn wide attention in recent years. Guo (2017) identified 781 papers published in 2004-2013 by eight key academic journals on educational policies in China and concludes that most of these studies focused on practical issues (84.4\%) rather than theoretical research (11.8\%) (p. 170). She uses two tables to illustrate the distributions of the two areas as shown in Tables 1 and 2.

With the findings in mind, Guo (2017) concludes that these studies peaked around 2010-2011 which shows a growing trend in general from 2004 to 2013, and that most of them focused on policy issues on equity and quality in education that are consistent with the overall patterns of socio-economic and political development in China (pp. 177-179). In addition to Guo (2017)'s study on educational policy development in China, there also exist some studies on examining educational policy development at different levels. Zhu et al. (2017) identify the impact of higher education policy development on economic 


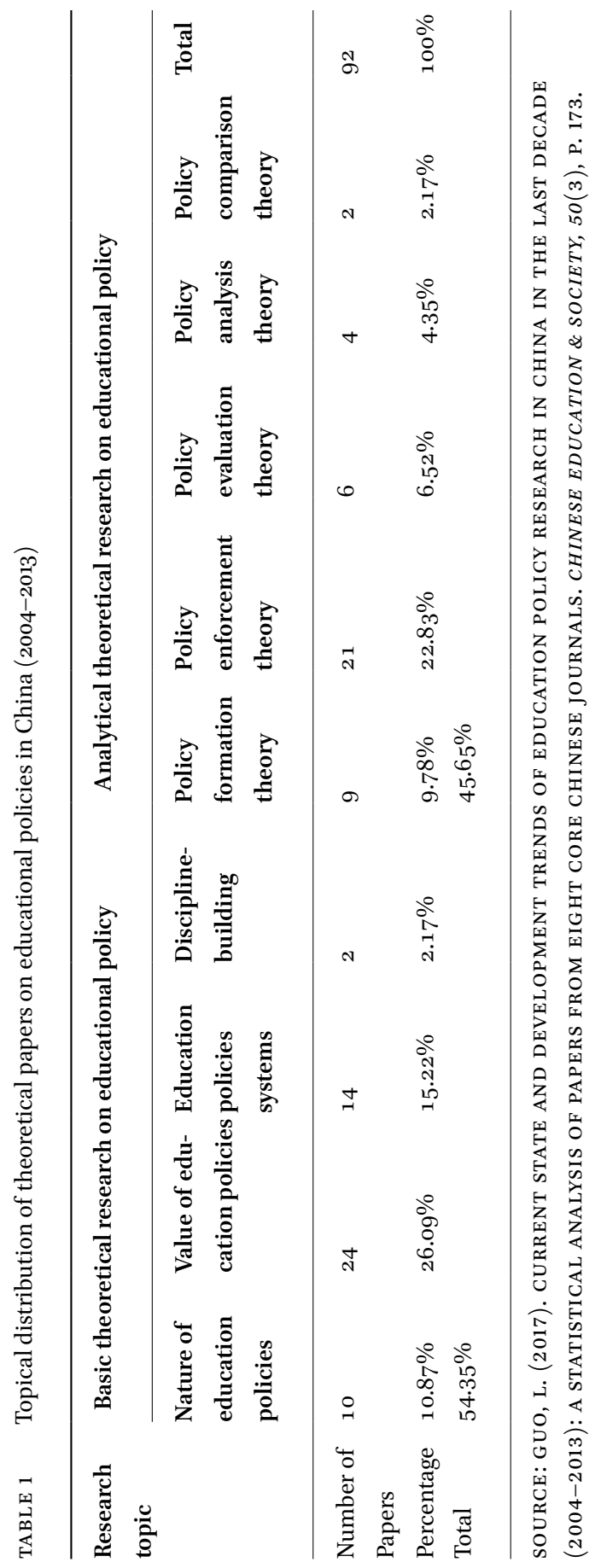




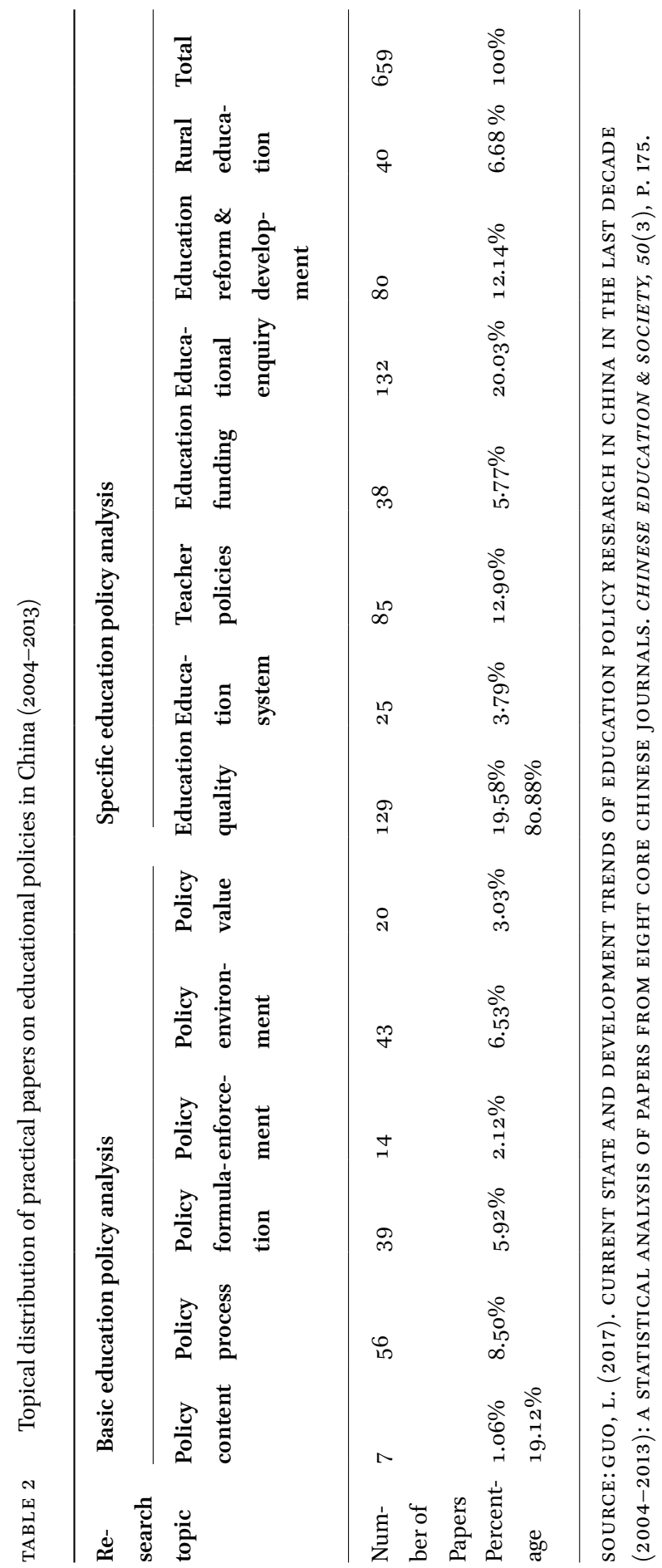


growth in China, especially for central region in China. They argue that educational policy development offers an indirect role in accelerating the comprehensive development of higher education. Li (2016a) builds upon his earlier studies on higher education policies in China and constructs a Chinese model of higher education development, i.e., the Chinese University 3.o. He also proposes a Chinese model of teacher education to conceptualize the future of teacher education policy development in China ( $\mathrm{Li}, 2016 \mathrm{~b} / \mathrm{c})$. Additionally, Hong and Chen (2017) conclude that educational policy develop as one of efficient approaches to the changes of childhood education in China, and Wang (2017) offers an empirical analysis of the development of china's higher vocational education to highlight the significance of updating vocational education policies.

Educational policy development has been widely perceived as fundamental transformations in China since the national reform and open-up policy in 1978 and speeded up in the early 200os. These market-oriented reforms and the pursuit of rapid economic growth in a global economy have significantly impacted China's education policy and development (Ngok, 2007). It is observed that these studies have focused on at least four core themes, i.e., equality in terms of a democratic mission of education for every citizen, quality in terms of individual and social productivity, efficiency as a national priority based on practicality, and rejuvenation of the nation for nation-building and global status, as summarized by Li (2017a).

Although there has been a growing trend in terms of literature published on educational policies in China in the past few decades, many serious researchers have argued that there are critical concerns on them (e.g., Li, 2017a; 2016b). First, there is a dearth of empirical studies on educational policies in China, as very few of them have been based on empirical evidence. This is particularly true in examining how teacher education institutions in China have responded to new national initiatives of teacher education reform in recent years. Secondly, very limited researchers in Mainland China have demonstrated solid training in the disciplinary field of policy studies, and their analyses presented tend to have been neither rigorously designed with appropriate analytic frameworks, nor conducted by employing a justifiably selected research methodology. Finally, the Chinese policy community tends to cater to the "political correctness" of educational initiatives. Under such a research culture, real policy concerns are easily neglected or covered up, and unfavorable findings are usually discouraged.

This paper attempts to address these gaps by conceptualizing a "MultiFlows" Approach and critically examining educational policy development in 
China with three key policy streams, i.e., basic education, teacher education, and higher education.

\section{$3 \quad$ Flow and the Multi-Flows Approach}

A "flow" or "autotelic experience" as a perspective is a zone with the intellectual state of operation for achievement with specific skills viewed from positive psychology (Csikszentmihalyi, 1975; 2014). The term "flow" is characterized by complete absorption in what one does, and a resulting loss in one's sense of space and time (Helprin, 1978; Snyder \& Lopez, 2007). To Csikszentmihalyi (2014), "flow" denotes "the holistic sensation present when we act with total involvement" (p. 136). According to him, flow theory includes three conditions, i.e., direction and structure to a task, clear and immediate feedback, and the completed task at hand (Csikszentmihalyi, 2014). Nakamura and Csikszentmihalyi (2005) identify the following six factors as encompassing an experience of "flow", including (a) intense and focused concentration on what one is doing in the present moment; (b) merging of action and awareness; (c) loss of reflective self-consciousness (i.e., loss of awareness of oneself as a social actor); (d) a sense that one can control one's actions; (e) distortion of temporal experience; and (f) experience of the activity as intrinsically rewarding (p. 9o).

In education, such an idea from positive psychology has been employed to measure student's ability to achieve "flow". For example, it is suggested that overlearning enables the mind to concentrate on visualizing the desired performance as a singular, integrated action instead of a set of actions (Csikszentmihalyi, 2014). In this sense, policy analysis can be seen as flows of intellectual work, by which policy researchers are motivated to take challenges of investigating the process of policy with their disciplinary approaches, as illustrated by Csikszentmihalyi (2014, pp. 147, 212-213, 248). Thus, the Multi-Flows Approach is conducive to the investigation of the dynamism and complexity of policy development in China's education.

The original flows from Csikszentmihalyi $(1975 ; 2014)$ are modelled and adapted respectively by this paper to economic flows, political flows, cultural flows, and international flows as key analytical elements. For educational policy development, the metaphor of flows is applied to identifying rationales for educational policy development contextually involving the four situational factors for a prosperous zone by governmental agencies and educational institutions in China. Economic flows are mainly identified for policy choices on allocating resources and needs to maximize outputs, while cultural flows 
involve educational traditions and values of a professional community in China. Political flows refer to the political direction of educational policies, and international flows are customized to examine activities in cross-border endeavors. In addition, all the four flows are interdependent to each other to holistically and historically investigate the landscape of educational policy development in China. It has a unique power in complementarily interpreting the complexity and dynamism of educational policy development in China, with analytical functions in parallel to the Multiperspectival Approach advocated by Li (2016b).

The emerging Multi-Flows Approach is constructed based on both current literatures related to educational policy development and realities in China. China's education policy development - as an indisputable part of its political system - serves as the direct products of socio-economic, political, cultural and international changes (Gu \& Liu, 2008; Lin, 2004; Shen, 2006). Essentially, policy development in China is never an isolated phenomenon. Rather, its form, structure and implementation are all subjected to politics, economy, culture, as well as international relationships in different times. Constrained from these factors, it has undergone various stages of establishments, adjustments, reforms and innovations (Ge \& Chen, 2005; Hu, 2006; Liu, 2004). In this sense, educational policy development in China is considered the dynamic embodiment, direct or indirect reflections, and corresponding values of political economy in the globalization process. Based on such a recognition, the Multi-Flows Approach is conceptualized with Fig. 1 for the studies of education policy development in China.

Political Flows

Economic Flows

Educational

Policy Development

Cultural Flows

in China

International Flows

FIGURE 1 Educational policy development in China from the multi-flows approach

Note. Adapted from Csikszentmihalyi (2014), pp. 147, 212-213, 248. 


\section{Educational Policy Development in China from the Multi-Flows Approach}

With the Multi-Flows Approach, this section uses basic education, teacher education, and higher education as three examples of policy streams to illustrate the development of educational policies in China since the 21st century. The economic flows, political flows, cultural flows, and international flows all contribute to the investigations of the China phenomenon of educational policies at different levels and times.

\subsection{Basic Education Policies}

In the level of basic education in China, a key national initiative is the law of 9-year compulsory education that has been put forward to provide basic learning conditions for all school-aged children. The Compulsory Education Law enacted in 1986 aims to provide legal imperatives to guarantee the human rights of learning and education for Chinese children. The law was revised and enhanced in 2006, which has allowed 145.35 million students enrolled in 218,900 schools by 2016 (The Ministry of Education [The MOE], 2017).

From the view of economic flows, it is obvious that Chinese governments and educational institutions at all levels make policy choices based on educational resources available to maximize educational outputs for students. Chinese policymakers and practitioners believe that the increasing enrollment rate of basic education can serve as a driving engine of the socio-economic development, as the literacy rate of a state is rationally reasoned as a necessary condition for socio-economic productivity. In 1999 the central government of China held the 3 rd National Meeting of Educational Work and issued a guideline to deepen educational reform to accelerate economic development. For this reason, the central government has systematically implemented the 9-year compulsory education initiative and claimed this goal has been fully achieved around the early 2010 .

Although it is hard to establish a direct cause-effect relationship between the growth of China's gross domestic product (GDP) and fiscal investments and promotion rates of students in basic education, it is unequivocal that in general they have shared the same historical trends in the past few decades, as evidenced in Fig. 2. The overall correlational patterns of annual GDPs and four indicators of basic education, e.g., promotion rates from junior to senior secondary schools, fiscal expenditures in basic education, etc., all appear positively related to one another during the period of 2001 to 2017. With the time gap of three years between educational expenditures and GDPs over these years viewed from Fig. 2, it is reasonably assumable that basic education, including 
the 9-year compulsory stage, has been serving as one of driving engines for the radical economic growth of China. On the other hand, the solid growth of China's economy in the same period has provided necessary and reliable financing for the development of basic education.

Historically, political flows have been observable on basic education policy development in China in the past several decades, referring to the determination of political efforts in directing educational initiatives for national survival and building. In fact, they echo well elitism in Western societies, which often views power and value preference of public policy as determined by ruling class (Asal \& Blake, 2006; Capano, 1996). A series of educational conference and relevant documents are issued to reflect the political reality. In 2002, Chinese government issued The Notice on Several Concerns for Strengthening the Management of Basic Education, targeting at a new generation of socialist

- - - Expenditure in Billion RMB

- - - Expenditure Per Capita in Hundred RMB (Secondary)

- - - Expenditure Per Capita in Hundred RMB (Elementary)

- - - Promotion Rate from Junior to Senior Secondary Schools

GDP in Trillion RMB

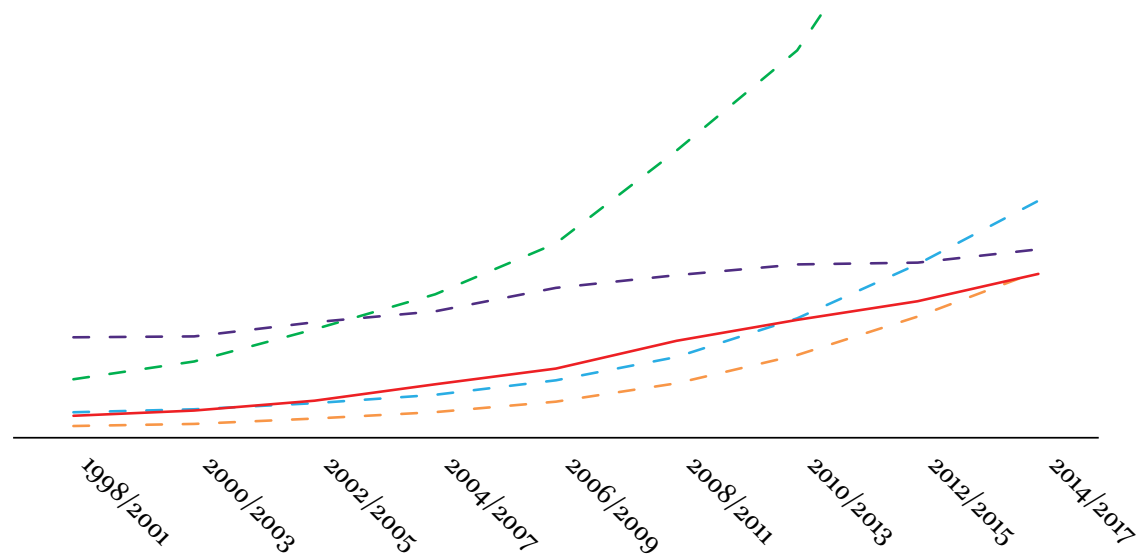

FIGURE 2 Historical trends of basic education and GDP growth in China (2001-2017)

Note. Data from China Educational Finance Statistical Yearbook 1999-2018 by the MOE and the National Bureau of Statistics of China (1999-2018) and China Statistical Yearbook 1999-2018 by the National Bureau of Statistics of China (1999-2018). GDPs are in odd years (2001-2017) while all other data in even years (1998-2014), accordingly. The data for GDPs and those for basic education (e.g., promotion rates from junior to senior secondary schools, educational expenditures, etc.) were collected in parallel with a 3-year lag, given that in general junior secondary school students have to go through a learning process of three years before their graduation for possible employment. 
citizens in contemporary China. In 2017, The Supervisory and Assessment Approaches for Quality and Balanced Development of Compulsory Education in Counties concentrates on the quality of basic education, the training of talents at all levels, and the promotion of socialist modernization.

From the view of cultural flows, basic education policies have been featured with an enduring focus on promoting traditional values of Chinese culture as guidelines for curriculum, schooling and learning. In recent years educational policy development in China has witnessed a revival of traditional expectations of teachers, e.g., role models for students, and professional and ethical development for enhancing teaching and learning. It is consistent throughout the past two decades that the traditional moral and ethical values of teachers have been always highlighted in the development of basic education policies.

TABLE 3 Key initiatives of basic education

\section{Period Initiatives}

2001 The Decision on the Reform and Development of Basic Education

2002 On Concerns on Strengthening the Management of Basic Education

2004 The Rejuvenation Action Plan for Education (2003-2007)

2006 The Compulsory Education Law of the People's Republic of China (Rev., 2006)

2005 The Guidelines on Fully Promoting the Three Application Models of Modern Distance Education in Rural Schools

2010 The Planning Guidelines for Mid- and Long-Term Educational Reform and Development 2010-2020

2011 The Regulations of Health Education in Schools

2013 The Professional Standards for Compulsory Schools Principals

2013 On Improving Funding Mechanism of Primary Village Schools and Teaching Units

2014 The Implementation Opinions on Deepening the System Reform of Examination and Admission

2016 The 1oth Five-Year Plan of Poverty Reduction through Education

2017 The Supervisory and Assessment Approaches for Quality and Balanced Development of Compulsory Education in Counties

2017 The Prioritized Plan for the Popularization of Secondary Education (2017-2020)

2017 Management Standards for Compulsory Education Schools (Pilot)

2017 The Senior High School Curricular Plans and Standards (2017 ed.)

SOURCE: THE MOE. (N.D.) RETRIEVED FROM THE MOE WEBSITE: HTTP://WWW.MOE .GOV.CN 
Policies of basic education are also seen a process of continuous engagements in cross-border objectives and implementation. China's 9-year compulsory education policy has been popularized by following The 1948 Universal Declaration of Human Rights as UNEsco's milestone in achieving universal human rights of education for all children in the world. In fact, China is one of few developing countries in the world that have first fully implemented compulsory education after The 1948 UNESCO Universal Declaration, and in recent years China is developing fast toward a 12-year compulsory system of education. Obviously, China's earlier formation and borrowing of basic education policies have largely benefited from the process of globalization, such as curricular standardization and school reforms. Since the early 2010s, China has successfully moved to a new status as a global leader of educational improvement, given the fact that its educational achievement is widely recognized and appreciated with admiration by such traditionally advanced countries as Canada, France, Germany, Japan, the U.K., the U.s., etc.

\subsection{Teacher Education Policies}

The development of teacher education policies in China have been shaped by socio-economic, political, cultural and international forces in the past decades, and is thus inherently engageable with their respective flows for the analysis.

In lieu of economic flows, teacher education policies have been maneuvered as a crucial instrument for China's economic development at the first stance, similar to those policies for the improvement of basic education. With the similar logic, they are imbedded in economic driving flows. For example, The Supplementary Document on Some Concerns on the First Confirmation of Teacher Qualifications was enacted in 2001 to vibrantly develop teacher education to meet various economic demands in a radically changing context. The rationales for teacher education reform have been theorized by Chinese policymakers and practitioners as the following equation:

$$
\mathrm{TE} \rightarrow \mathrm{CT} \rightarrow \mathrm{QE} / \mathrm{SA} \rightarrow \mathrm{QLF} \rightarrow \mathrm{MD} / \mathrm{EG} \rightarrow \mathrm{NAC}
$$

By this simplified equation as summarized by Li (2016b, p. 51), it is reasoned that a better system for teacher education (TE) prepares more competent teachers (CT), better prepared teachers improves the quality of education and student achievement (QE/SA), higher educational quality and student achievement brings about higher quality of labor force (QLF), higher quality of the labor force tremendously benefits China's modernization, development and economic growth (MD/EG) and eventually leads to China's national achievement and competitiveness (NAC). Based on these assumptions, teacher education 
has been taken as a driving force for educational improvement and economic development.

Political flows facilitate a view of teacher education policies in China as political initiatives for national development. In 2018, The Opinions on Fully Deepening the Reform and Construction of Teaching Force in the New Era was released as an ideological guideline to highlight political demands for the reform of teacher education system. At the same year, The Action Plan for the Revitalization of Teacher Education (2018-2022) appeals for heightened political expectations for the reform of teacher education system in China. Over the last two decades, the Chinese government has repeatedly urged that high quality education is the foundation of socialist construction of modernization, and that a highly qualified teacher workforce is the key to promoting it (The CPCCC \& the State Council, 1999, June 13; The State Council, 2001, May 29; The State Council, 2010, May 5).

From the perspective of cultural flows, traditional values of teachers are manifest in teacher education policies, represented by a Confucian expectation of teachers' role. In Confucian tradition, teachers have served as respected cultural symbols (Li, 2016b, pp. 17-18). Xun Zi (313-238 вСE), a Confucian philosopher and reformer in the 3 rd century $\mathrm{BCE}$, made the point that teachers must be respected if the nation was to rise (Knoblock, 1994, p. 231). Later in the Tang Dynasty, Han $\mathrm{Yu}(768-824 \mathrm{CE})$ theorized the responsibility of the teacher as encompassing the following three roles - transmitting moral values and principles, delivering knowledge and skills, and solving the puzzles that arise in learning. Lee (2000) observes that "the Chinese people have since cherished this dictum as the best characterization of a model teacher" (p. 258). It is in this cultural sense, as pointed out by $\mathrm{Li}(2016 \mathrm{~b}, \mathrm{p} .18)$, that teachers have historically become widely respected cultural symbols, and have been venerated with the highest sociopolitical status. This instrumentalist view of rationales for the national reform of teacher education is deeply rooted in a Confucian tradition of the practicality of Zhong-Yong, and such a pragmatism can be widely observed in almost all national reforms vibrantly ongoing in China in recent decades $(\mathrm{Li}$, 2016b, pp. 203-205).

Taken from the perspective of international flows, Chinese policymakers and educators have also been open to embrace teacher professionalism developed in the West. Recent policy documents have reiterated that teachers must first be lifelong learners and researchers. For example, The Opinion on the Reform and Development of Teacher Education during the Tenth Five-year National Plan by the MOE (2002, February 6) requires that teachers

must promote their awareness of lifetime learning; continue extending their professional knowledge and skills ... actively participate in teaching 
TABLE 4 Key initiatives of teacher education

\section{Period Initiatives}

\begin{tabular}{|c|c|}
\hline 2000 & The Regulations of Teacher Qualification \\
\hline 2002 & $\begin{array}{l}\text { The Opinion on the Reform and Development of Teacher Education } \\
\text { during the 1oth Five-Year Plan }\end{array}$ \\
\hline 2004 & $\begin{array}{l}\text { A New Round of Comprehensive Quality Training Program for School- } \\
\text { teachers in Ethnic and Poor Areas and New Curriculum Teacher Train- } \\
\text { ing Plan (2004-2008) }\end{array}$ \\
\hline 2005 & $\begin{array}{l}\text { The Opinion on Further Strengthening and Improving Teacher } \\
\text { Education }\end{array}$ \\
\hline 2007 & $\begin{array}{l}\text { The Implementation Approaches of Free Teacher Education Programs } \\
\text { in Key National Normal Universities under the Ministry of Education }\end{array}$ \\
\hline 2008 & The Guidelines on Performance Pay in Compulsory Education Schools \\
\hline 2010 & $\begin{array}{l}\text { The National Training Project for Elementary and Secondary School- } \\
\text { teachers (Guopei Jihua) }\end{array}$ \\
\hline 2011 & The Curricular Standards for Teacher Education (Provisional) \\
\hline 2012 & $\begin{array}{l}\text { The Professional Standards for Kindergarten, Elementary and Second- } \\
\text { ary Schoolteachers (Provisional) }\end{array}$ \\
\hline 2012 & The Opinions on Strengthening the Construction of Teaching Force \\
\hline 2013 & $\begin{array}{l}\text { The Guidelines of Deepening the Reform of the Training Models of } \\
\text { Schoolteachers for the All-round Improvement of Training Quality }\end{array}$ \\
\hline 2013 & $\begin{array}{l}\text { The Approaches of Qualification Examination of Schoolteachers } \\
\text { (Provisional) }\end{array}$ \\
\hline 2014 & The Notice on Standardizing the Staffing of Urban and Rural Schools \\
\hline 2015 & The Supporting Plan for Rural Teachers $\left(2015^{-2020}\right)$ \\
\hline 2018 & $\begin{array}{l}\text { The Opinions on Fully Deepening the Construction and Reform of } \\
\text { Teaching Force in the New Era }\end{array}$ \\
\hline 2018 & $\begin{array}{l}\text { The Action Plan for the Revitalization of Teacher Education } \\
(2018-2022)\end{array}$ \\
\hline
\end{tabular}

SOURCE: THE MOE. (N.D.) RETRIEVED FROM THE MOE WEBSITE: HTTP://WWW.MOE .GOV.CN

and educational research and be encouraged for the exploration and innovation of knowledge and skills.

Teacher education policies have seen professionalism and professionalization as imperatives of global trends of educational reform. For example, Guan Peijun (2003), the then-director of Teacher Education Department at the MOE, appeals for teacher professionalization in the following way (p. 4): 
Since the 1980 s, teacher professionalization has become a strong trend worldwide. It has significantly speeded up the establishment of new theories and new systems of teacher education in the world .... We must seriously study the experiences and development trends of teacher education in other countries, examine the reality of teacher education in our country and promote its development.

Teacher professionalism has been a worldwide educational move since the 1960s, and teacher education policies in China have followed this international trend to promote the professional status of teachers and improve the quality of their work. In 2000, the MOE promulgated The Regulations of the Ordinance of Teacher Qualification to enhance the implementation of the licensing system nationwide, which turns out an effective mechanism to enhance the capacities of students, teachers and schools in China.

\subsection{Higher Education Policies}

Since the turn of the 21st century, higher education policies in China have resulted from sextuple discourses, i.e., unprecedented quest for world-class universities (WCUs), systematical marketization, revolutionary massification, structural optimization, institutional digitalization, and all-round internationalization. The latest stage of the Chinese model of the university is coined as the Chinese University 3.0 by $\mathrm{Li}(2016 \mathrm{a} ; 2018)$, in the fact that it differs fundamentally from its earlier forms. Higher education policies in China have aimed to systematically upgrade higher education institutions (HEIs) with four ideological imperatives, i.e., quality, equity, efficiency, and service to the nation building of China.

Taking the perspective of economic flows, the central government is seen to play a dominant role to continuously pour necessary resources into HEIs in the past two decades. With more than enough financial investments, HEIs are expected to maximize their outcomes in terms of students' learning, knowledge production and transfer, and services to local, national and international communities. The financial constraints of HEIs in the 1980s-1990s have been significantly relieved, thanks to the rapid economic growth achieved in China, which has become the second largest country in the world in terms of gross domestic product since 2010 (Barboza, 2010). More importantly, the research capacity of Chinese universities has grown remarkably in these decades. For example, China's world share of SSCI publications has increased from $0.01 \%$ in 1978 to $0.67 \%$ in 2007 , with more than half of them were published in the past decade (Liu \& Liu, 2009), mainly due to the accelerated investment in terms of funding and staffing. 
Consistently, it is observed that the growth of China's GDP and student enrollments and fiscal expenditures in higher education, including annual investments in research and development ( $R$ \& D), have shared the same historical trends in the past few decades, as evidenced in Fig. 3 - similar to those with regard to basic education in Fig. 2. The overall correlational patterns between them appear positively related to each other during the period of 2001 to 2017. Again, with the time gap of four years between fiscal expenditures of higher education and GDPs over these years viewed respectively from Fig. 3, it is reasonably assumable that higher education - together with $R \& D$, as well as basic education - has too been serving as one of driving engines for the radical economic growth of China. The solid growth of China's economy has vice versa provided necessary and reliable financing for the development of higher education in the same period.

Political flows are similarly observable in higher education policy development in China, as almost all the initiatives for higher education development

- - - Expenditure in Billion RMB

- - - Expenditure per capita in Thousand RMB

- - - R \& D in 10 Billion RMB

- - - Gross Enrolment Rates

GDP in Trillion RMB

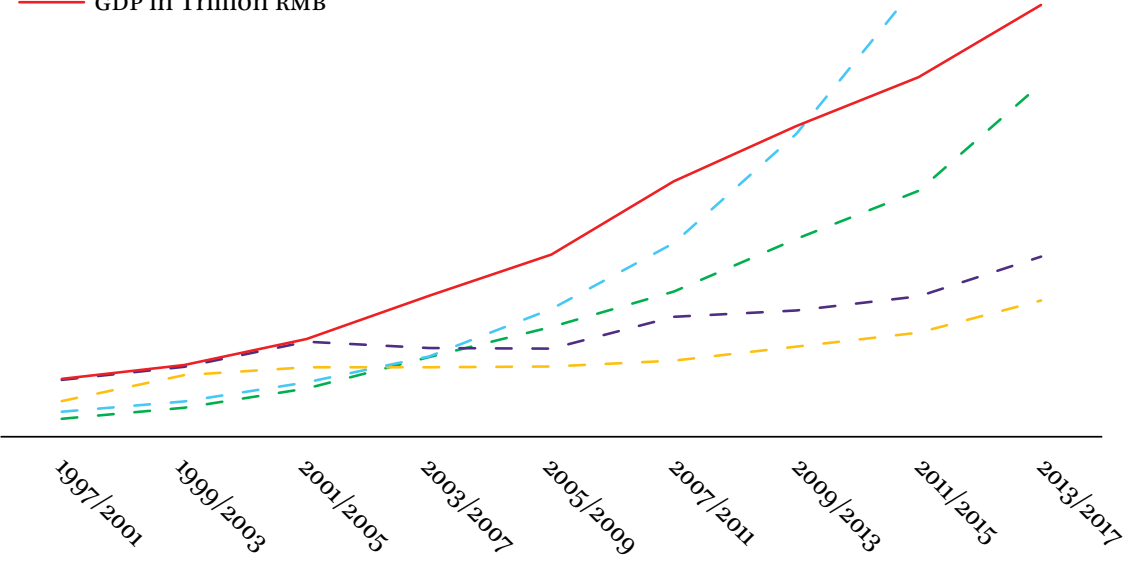

FIGURE 3 Historical trends of higher education, R \& D and GDP growth in China (2001-2017)

Note. Data from China Educational Finance Statistical Yearbook 1998-2018 by the moe and National Bureau of Statistics of China (1998-2018) and China Statistical Yearbook 1998-2018 by the National Bureau of Statistics of China (1998-2018). The data for GDPs (2001-2017) and those for higher education including R \& D (1997-2013) were collected respectively with a 4-year lag, given that there is a general requirement of 4-year programs for college students before their graduation for possible employment. 
have been driven by political imperatives. These political imperatives are demanded nationally due to the sextuple discourses mentioned earlier on quality, equity, efficiency, and service. In terms of geographical equity of higher education development across the country, The Revitalization Plan of Higher Education in Western Regions(2012-2020) was announced in 2013 by the central government to fight against the imbalance between regions in developed East China and relatively poor West China. The revitalization plan focuses on the promotion of more even development of HEIs in the mid- and west-regions which have traditionally lagged behind those in East China. The targets of policy endeavors include institutional and disciplinary development, personnel training, research capacity, services and networking, infrastructure, technological innovations, etc.

The political imperatives also prioritize development in quality that is tightly associated with nation building. The most notable agendas include Projects 211 and 985 in the late 1990s, and the so-called "Dual World-Class Construction Movement" officially announced in 2017 with The Implementation Guidelines for the Comprehensive Promotion for World-class Universities and World-class Disciplines. The latest policy aims to remarkably improve the institutional and disciplinary qualities of HEIs all over the country, benchmarking global standards of higher education. The 2018 Academic Ranking of World Universities by Shanghai Jiaotong University shows that there are 12 and $5^{\circ}$ Chinese universities ranked in the top 200 and 500 world universities, respectively, while almost none of them was so competitive ten years ago.

From the standpoint of cultural flows, higher education policies have highlighted their role in the promotion and shaping of traditional Chinese values and norms. Back to earlier times in the 199os, Chinese leaders have kept appealing for the cultural mission of higher education. For example, Jiang Zemin, then Secretary General of the Communist Party of China, presided over a ceremony to celebrate Peking University's 1ooth anniversary, and he expected the mission of world-class Chinese universities in this way: (a) cradles for nurturing creative, highly qualified talent; (b) frontiers for the exploration of new knowledge and an unknown world; (c) key forces of knowledge transfer from innovation to real productivity, and; (d) bridges of domestic and global cultures (Jiang, 1998). More recently, the cultural mission of higher education in China has been integrated with traditional norms and ethics of Chinese culture by relevant policy documents. Specifically, The Ten Guidelines of Professional Conduct of College Faculty in the New Era (Ten Guidelines) enacted by the MOE in 2018 requires faculty members to uphold decent cultural values and professional norms in their professional, daily conducts. 
In terms of internationalization flows, Chinese HEIs have endeavored to rapidly internationalize themselves in mutual ways. The first and dominant mode is the inbound internationalization. By 2016, there were a total of 440,000 international students from 205 countries and regions studying in Chinese universities (The Editorial Board of the People's Republic of China Yearbook 2017, p. 651), 921\% from 4,3084 from 164 countries and regions in 1998 (The Editorial Board of the People's Republic of China Yearbook 1999, p. 1085).

On the other hand, Chinese HEIs have actively engaged in the outbound internationalization, or a process of "Sinicization" termed by $\mathrm{Li}(2017 \mathrm{~b})$. One example is that China has contributed to the international community a new discourse of wCUs, which is a unique phenomenon in terms of higher education development in a post-colonial context that has attracted much global attention in recent years. Another example - related to WCUs - is the rapid spread of the Confucius Institutes (CIs) and Classrooms (CCs) around the

TABLE 5 Key initiatives of higher education

\section{Period Initiatives}

\begin{tabular}{|c|c|}
\hline 1999 & The Higher Education Law \\
\hline 2007 & The Guidelines of the 11th Five-Year Plan for Educational Development \\
\hline 2010 & $\begin{array}{l}\text { The Guidelines on the Promotion of College Education of Students' In- } \\
\text { novation, Entrepreneurship and Self-employment }\end{array}$ \\
\hline 2011 & $\begin{array}{l}\text { The Opinions on Implementing Education and Training Plan for Tal- } \\
\text { ented Engineers }\end{array}$ \\
\hline 2013 & $\begin{array}{l}\text { The Revitalization Plan of Higher Education in Western } \\
\text { Regions }(2012-2020)\end{array}$ \\
\hline 2015 & The Higher Education Law (Rev.) \\
\hline 2017 & $\begin{array}{l}\text { The Implementation Guidelines of the Improvement Project of Ideo- } \\
\text { logical and Political Work in Higher Education Institutions }\end{array}$ \\
\hline 2017 & $\begin{array}{l}\text { The Implementation Guidelines for the Comprehensive Promotion for } \\
\text { World-class Universities and World-class Disciplines }\end{array}$ \\
\hline 2018 & $\begin{array}{l}\text { The Opinions on Enhancing the All-round Capability of Talent Cultiva- } \\
\text { tion by Accelerating the Construction of High Quality Undergraduate }\end{array}$ \\
\hline & Education \\
\hline 2018 & $\begin{array}{l}\text { The Ten Guidelines of Professional Conduct of Faculty in the New Era } \\
\text { (Ten Guidelines) }\end{array}$ \\
\hline
\end{tabular}

SOURCE: THE MOE. (N.D.) RETRIEVED FROM THE MOE WEBSITE: HTTP://WWW.MOE .GOV.CN 
world since 2004. A demand-led response modality has enabled hundreds of Chinese universities, many enlisted in Project 211 or 985, to partner with their international counterparts to set up the CIs and CCs worldwide, the largest project of international collaboration in language and cultural exchange in human history (King, 2013; Li \& Tian, 2016). By the end of 2017, 525 CIs are operating in 138 countries and areas, with 54 in Africa, 118 in Asia, 173 in Europe, 19 in Oceania and 161 in the Americas, in addition to 1,113 CCs in 79 countries, registering over millions of local learners (The Hanban, 2017). As concluded by $\mathrm{Li}$ and Tian (2016), the new way of the collaboration with the overseas partners of Chinese HEIs through CIs is a milestone to their internationalization, which signals that they are in an unparalleled stage that goes global in real sense.

Since the 21st century, educational policy development in China has witnessed a fundamental transformation from tradition to modernization and from localization to internationalization in a global age of political economy. The interplays suggested by the Multi-Flows Approach in the three key policy streams examined can illustrate important implications for policy studies.

First, the Multi-Flows Approach from Csikszentmihalyi (1975; 2014) empowers policy analysts in a multi-perspectival position to examine key aspects, elements and features of policy initiatives, as one type of flows may help bring in uniquely meaningful insights for policy analysis than another. Additionally, it may help investigate the interdependent, interrelated, or even hidden complexity and dynamism of educational policy development in complementary ways. Such a complementary, emancipatory and more balanced analytical power can be illustrated by a classical Chinese poem written by Su Shi in the 11th century on how mountains may appear as ridges or peaks, depending on the viewer's stances at different distances and altitudes:

A Signatory Poem on the Wall of the West Forest Temple by Su Shi From the side, a full range; from the end, a single peak

From far, near or top, bottom, none of them alike

Why can't I tell the true Mount Lu

For I am wandering in the Mountain deep

As Xu (2009) points out, the poem by Su Shi vividly illustrates that it is always difficult to find out truth which is often perceived differently depending on varied, constrained perspectives (p. 180). Similar to this philosophical notion is 
a Zen Allegory of the Rock Garden in the Ryoan-ji Temple in northwest Kyoto, Japan.

Second, educational policy development in China since the 21st century has experienced a process through which such factors as economic, political, cultural and international forces each play a crucial role in educational development, if viewed from the Multi-Flows Approach. The Multi-Flows Approach may facilitate policymakers, practitioners or researchers to analyze policy problems, instruments, strategies, implementation and evaluations with a focus on any of economic, political, cultural and international flows. The different focus can benefit policy communities around the world with varied directions for the change of education resulting in significant improvement (Langley et al., 2009, p. 2).

Third, with the Multi-Flows Approach, none of the economic, political, cultural and international flows is seen as a single force that can independently shape educational policy development in China or globally, without the convergence of other forces. This implies that for any public policy in education policymakers, implementers and other stakeholders must ensure a comprehensive consideration with the interdependent, converging effects of the forces to prioritize and maximize its outcomes, which may be easily missed by any single force of them.

Finally, it must be realized that the function and significance of the MultiFlows Approach for policy studies in education are not limited to the four flows conceptualized by this paper. In fact, there are many more flows beyond them that may supplement each other, and all contribute to the advancement of policy studies in education. For example, they may include rational flows, historical flows, philosophical flows, critical flows, feminist flows, post-modernist flows, etc., to name a few. Although they may appear differently (in some circumstances contrastingly), the power of analysis and interpretation remains stronger, more balanced, complementary and multifaceted.

\section{6}

\section{Conclusion}

Since the early 2010s, China as the largest educational system in the world has moved to a recently emerging status as a global leader of educational excellence, given the fact that its achievement is widely recognized and appreciated with admiration by many developed countries. In recent years policymakers, educational leaders, educators, and other stakeholders from these countries frequently visit China for closer and handy learning of educational reform and improvement together with their local counterparts - whether this be termed 
reciprocal learning or policy borrowing (Phillips, 1989; Wei, 2017). Within the past few decades in a post-colonial context, China has amazingly managed to transform itself from a learner in the 2oth century to a re-rising leader of international experience of educational excellence.

In the new wave of worldwide reform and improvement in education, public policies play a crucial role in shaping its varied directions, strategies, implementations and outcomes. The lesson illustrated and learned from the Multi-Flow Approach on educational policy development in China since the 21st century shows that various perspectives - including economic, political, cultural and international flows and beyond - are conducive for policymakers, school leaders, educators, parents, and other stakeholders around the globe to look at public policies in education in more balanced, dynamic and complementary ways. It is the stances of these stakeholders in their respective socio-political, economic, gendered, cultural, religious and linguistic contexts that determine how alternative perspectives may be taken to appropriate policy action and analysis for the success of school reform and educational improvement.

\section{References}

Asal, V., \& Blake, E.L. (2006). Creating simulations for political science education.Journal of Political Science Education, 2(1), 1-18.

Barboza, D. (2010). China passes Japan as second-largest economy. New York Times, Aug. 16, p. B1.

Belfield, C.R., \& Levin, H.M. (2002). Education privatization: Causes, consequences and planning implications. UNESCO, International Institute for Educational Planning.

Capano, G. (1996). Political science and the comparative study of policy change in higher education: Theoretico-methodological notes from a policy perspective. Higher Education, 31(3), 263-282.

Csikszentmihalyi, M. (1975). Beyond boredom and anxiety. San Francisco: Jossey-Bass.

Csikszentmihalyi, M. (2014). Toward a psychology of optimal experience. In Flow and the foundations of positive psychology: The collected works of Mihaly Csikszentmihalyi (pp. 209-226). Dordrecht: Springer.

Ge, J., \& Chen, J.K. (2005). Historical perspective of teacher education policy in China. Heilongjiang Gaodeng Jiaoyu [Heilongjiang Higher Education Research], (7), 42-44.

Gu, M.Y., \& Liu, F.X. (2008). Gaige kaifang sanshinian Zhonguo jiaoyu jishi [Documentary of China's education of the 30 years of reform and open-up]. Beijing: People's Press. 
Guan, P.J. (2003). Wei quanmian jianshe xiaokang shehui zhunbei gaosuzhi jiaoshi [Preparing highly qualified teachers for a well-off society in an all-round way]. People's Education, (17), 2-7.

Guo, L. (2017). Current state and development trends of education policy research in China in the last decade (2004-2013): A statistical analysis of papers from eight core Chinese journals. Chinese Education \& Society, 50(3), 162-180.

Hayhoe, R. (2017). China in the center: What will it mean for global education? Frontiers of Education in China,12(1), 3-28.

Helprin, F. (1978). Applied mathematics as a flow activity. Unpublished manuscript, The University of Chicago.

Hong, X., \& Chen, J.J. (2017). A critical analysis of the changing landscape of early childhood education in Mainland China: History, policies, progress, and future development. In Early childhood education policies in Asia Pacific (pp. 31-50). Singapore: Springer.

King, K. (2013). China's aid and soft power in Africa: The case of education and training, Oxford: James Currey.

Knoblock, J. (1994). Xunzi: A translation and study of the complete works (vol. III). Stanford, CA: Stanford University Press.

Kogan, M. (2002). National characteristics and policy idiosyncrasies. In Higher education in a globalising world (pp. 39-52). Dordrecht: Springer.

Ku, H.M. (1906). The conduct of life, or the universal order of Confucius. London: John Murray.

Labaree, D.F. (1997). Public goods, private goods: The American struggle over educational goals. American Educational Research Journal, 34(1), 39-81.

Langley, G.J., et al. (2009). The improvement guide: A practical approach to enhancing organizational performance (2nd. Ed.). San Francisco, CA:Jossey-Bass.

Lee, T.H.C. (200o). Education in traditional China:A history. Leiden,Boston \& Koln: Brill.

Levy, D.C. (2007). Legitimacy and privateness: Central and Eastern European private higher education in global context. In Private higher education in post-communist Europe (pp. 279-297). New York: Palgrave Macmillan.

Li, J. (2018). The Chinese model of higher education. In M.A. Peters (ed.), Encyclopedia of educational philosophy and theory. Singapore: Springer. Retrieved from: https:// doi.org/10.1007/978-981-287-532-7_607-1.

Li, J. (2017a). Educational policy development in China for the 21st century: Rationality and challenges in a globalizing age. Chinese Education \& Society, 50(3), 133-141.

Li, J. (2017b). Ideologies, strategies and higher education development: a comparison of china's university partnerships with the Soviet Union and Africa over space and time. Comparative Education, 53(5), 1-20. 
Li, J. (2016a). Chinese University 3.o in a global age: History, modernity and future. In P.C.I. Chou \& J. Spangler (Eds.), Chinese education models in a global age: Transforming practice into theory (pp. 15-35). Singapore: Springer.

Li, J. (2016b). Quest for world-class teacher education? A multi-perspectival study on the Chinese model of policy implementation. Singapore: Springer.

Li, J. (2016c). The Chinese model of teacher education: The humanist way for Chinese learners, teachers and schools. In P.C.I. Chou \& J. Spangler (Eds.), Chinese education models in a global age: Transforming practice into theory (pp. 249-264). Singapore: Springer.

Li, J. (2012). World-class higher education and the emerging Chinese model of the university. Prospects, 42(3), 319-339.

Li, J. (2011). Equity, institutional change and civil society: The student experience in China's move to mass higher education. In R. Hayhoe, J. Li, J. Lin, \& Q. Zha (Eds.), Portraits of 21st century Chinese universities: In the move to mass higher education (pp. 58-93). Dordrecht \& HK: Springer/CERC.

Li, J. (2009). Fostering citizenship in china's move from elite to mass higher education: an analysis of students' political socialization and civic participation. International Journal of Educational Development, 29(4), 382-398.

Li, J., \& Tian, X.H. (2016). A global experiment in the internationalization of Chinese universities: Models, experiences, policies, and prospects of the Confucius Institutes' first decade. Chinese Education \& Society, 49(6), 411-424.

Liu, F.X. (2004). Woguo jiaoshi jiaoyu zhuanxing zhong de zhengce wenti [Policy issues in the transformation of teacher education in China]. Dangdai Jiaoyu Kexue [Contemporary Educational Science], (11), 19-23.

Liu, L., \& Liu, N.C. (2009). Bibliometric Analysis of SsCi Publications of China From 1978-2007. Information Science, 27(10), 1590-1594.

Nakamura, J., \& Csikszentmihalyi, M. (2009). Flow theory and research. In S.J. Lopez \& C.R. Snyder (Eds.), Handbook of positive psychology (2nd Ed., pp. 195-206). New York: Oxford University Press.

Nakamura, J., \& Csikszentmihalyi, M. (2005). The concept of flow. In C.R. Snyder \& S. Lopez (Eds.), Handbook of positive psychology (pp. 89-105). New York: Oxford University Press.

Ngok, K.L. (2007). Chinese education policy in the context of decentralization and marketization: Evolution and implications. Asia Pacific Review of Education, 8(1), 142-257.

Phillips, D. (1989). Neither a borrower or a lender be? The problems of cross-national attraction in education. Comparative Education, 25(3), 267-73.

Rhoades, G. (2001). Introduction to special section: "Perspectives on comparative higher education". Higher Education, 41(4), 345-352. 
Snyder, C.R., \& Lopez, S.J. (2007), Positive psychology: The scientific and practical explorations of human strengths. London, UK: Sage.

The CPCCC \& the State Council. (1999, June 13). Zhonggongzhongyang guowuyuan guanyu shenhua jiaoyu gaige quanmian tuijin suzhi jiaoyu de jueding [The cPccc and the State Council's decision on the deepening of educational reform and the full promotion of quality education]. Retrieved from the MOE Web Site: http:// www.moe.edu.cn/publicfiles/business/htmlfiles/moe/moe_177/200407/2478. html.

The Editorial Board of the People's Republic of China Yearbook. (2017). 2017 Zhonghua renmin gongheguo nianjian [People's Republic of China Yearbook 2017]. Beijing: People's Republic of China Yearbook Press.

The Editorial Board of the People's Republic of China Yearbook. (1999). 1999 Zhonghua renmin gongheguo nianjian [People's Republic of China Yearbook 1999]. Beijing: People's Republic of China Yearbook Press.

The Hanban. (2017). Confucius Institute annual development report 2017. Retrieved from: http://www.hanban.edu.cn/report/2017.pdf.

The MOE. (2017). 2016 nian quanguo jiaoyu shiye fazhan tongji gongbao [The national statistical communiqué of educational development 2016]. Retrieved from the MOE Web Site: http://www.moe.gov.cn/jyb_sjzl/sjzl_fztjgb/201807/t20180719_343508. html.

The MOE. (2002, February 6). Guanyu shiwu qijian jiaoshi jiaoyu gaige yu fazhan de yijian [The opinion on the reform and development of teacher education during the tenth five-year national plan]. Retrieved from the MOE Web Site: http://www.moe.edu.cn/ publicfiles/business/htmlfiles/moe/moe_290/200408/2546.html.

The MOE \& the National Bureau of Statistics of China. (1998-2018). China educational finance statistical yearbook 1998-2018. Beijing: China Statistics Press.

The National Bureau of Statistics of China. (1998-2018). China statistical yearbook 1998-2018. Beijing: China Statistics Press.

The State Council. (2010, May 5). Guojia zhongchangqi jiaoyu gaige he fazhn guihua gangyao 2010-2020 [The Guidelines of the Mid- and Long-Term Plan for Educational Reform and Development 2010-2020]. Retrieved from the Central People's Government of the People's Republic of China Web Site: http://www.gov.cn/jrzg/201007/29/content_1667143.htm.

The State Council. (2001, May 29). Guanyu jichu jiaoyu gaige yu fazhan de jueding [The decision on the reform and development of basic education]. Retrieved from the MOE Web Site: http://www.moe.gov.cn/jyb_xxgk/moe_1777/moe_1778/201412/ t20141217_181775.html.

Wang, M. (2017). An empirical analysis of the development of china's higher vocational education. Chinese Education \& Society, 50(5-6), 429-440. 
Wei, W. (2017). Education policy borrowing: Professional standards for school leaders in China. Chinese Education \& Society, 50(3), 181-202.

$\mathrm{Wu}, \mathrm{H} .(2008)$. Scientific analysis on the policy concerning intellectual property system in china. Frontiers of Law in China, 3(2), 198-219.

$\mathrm{Xu}, \mathrm{Z} . Y .(2009)$. An introduction of the selected works by Su Shi [Su Dongpo wenji daodu]. Beijing: China Radio International Press.

Zhu, T.T., Peng, H.R., \& Zhang, Y.J. (2017). The Influence of Higher Education Development on Economic Growth: Evidence from Central China. Higher Education Policy, 31(2), 139-157. 